Article

\title{
Innovative Behaviors, Employee Creativity, and Sustainable Competitive Advantage: A Moderated Mediation
}

\author{
Servet Nasifoglu Elidemir ${ }^{1, *(\mathbb{D},}$, Ali Ozturen ${ }^{1}\left(\mathbb{D}\right.$ and Steven W. Bayighomog ${ }^{2}(\mathbb{D}$ \\ 1 Faculty of Tourism, Eastern Mediterranean University, 99628 Gazimağusa, North Cyprus, Turkey; \\ ali.ozturen@emu.edu.tr \\ 2 Faculty of Business and Economics, Eastern Mediterranean University, 99628 Gazimağusa, North Cyprus, \\ Turkey; steven.bayig@emu.edu.tr \\ * Correspondence: servet.elidemir@emu.edu.tr
}

Received: 29 February 2020; Accepted: 9 April 2020; Published: 17 April 2020

check for

\begin{abstract}
It is challenging for enterprises that lack innovation and creativity to survive successfully in the market. Employee top role performance is not always sufficient to gain a competitive advantage, in which innovative behaviors and creativity can be counted as necessary ingredients to build. This study proposed and tested employee innovative behaviors (IB) and creativity as mediator and moderator, respectively, of the impact of high-performance work practices (HPWPs) on sustainable competitive advantage (CA). The resource-based view and job demands resources model provided the theoretical underpinnings for the developed hypotheses that were tested using a sample of 323 customer-contact employees of 4- and 5-star hotels. The results indicated that HPWP indirectly predicted CA via IB. Also, creativity moderated the impact of HPWPs on innovative behaviors positively and on competitive advantage negatively. Employee innovative behaviors can generate substantial returns to service organizations competing with quasi-homogeneous end-products. The relevant theoretical and practical implications are further discussed. The scope of the study calls for caution in the generalizability of the overall findings. The research acknowledges the need to extend the findings by explicitly accounting for national cultural profiles. This study fills the dearth of research in service innovation in the hotel industry by testing the mediating effect of IB on the HPWPs CA nexus and reveals the moderating role that employee creative traits have in these relationships.
\end{abstract}

Keywords: innovative behaviors; creativity; high-performance work practices; competitive advantage; 4- and 5-star hotels

\section{Introduction}

In the current age of digitalization and globalization, having creativity and innovativeness as a critical attribute in employees is becoming a mainstream demand for service and hospitality organizations [1]. The hospitality industry in the 21st century is rapidly changing. Customers' demands are changing, and so is their involvement in the value creation process of the firm. With these changes comes an alarming rate of economic and exponentially fierce competition, which requires innovation as a cornerstone for organizational sustainability [2,3]. Historically, the innovation literature has been skewed towards research on product and process innovation of manufacturing firms [3,4]. However, with an industry generating nearly $65 \%$ of the world's gross domestic product [5], service innovation research has sprung over the last decade [6]. Despite insightful findings generated by an accelerating interest in service innovation research, Storey Cankurtaran, Papastathopoulou, and Hultink [6] pointed out the nonexistence of evidence suggesting service firms' innovation enhancement. Possibly, 
the homogeneous essence of products provided to customers likely impairs firms' ability to leapfrog into absolute innovation. More studies are needed to take the lid off the required knowledge.

In contrast to manufacturing firms, (high customer-contact) service organizations heavily rely on their workforce, and their critical importance in the overall service delivery process has been emphatically acknowledged. Precisely, employees' frequent interactions with customers constitute a well-known source of information [7]. As such, their impact on service organizations' daily progress and incremental innovation is non-negligible, especially given customers' ever-changing expectations and growing demands that are prone to the hospitality industry [2,7]. Employee innovative behavior (hereafter IB) refers to "an initiative from employees concerning the introduction of new processes, new products, new markets or combinations of such into the organization" [8] (p. 8). It is an employee ability that can help improve overall service performance and quality $[2,3,9]$, critical cornerstones of firms' competitiveness, success, and survival [10,11].

Additionally, the job demand and customer-centric nature of the hospitality industry requires employees to be creative in their dealing and management of expectations if the organization must remain competitive in the fierce market. As suggested by Lee, Hallak, and Sardeshmukh [12], in order to anticipate the market and better prepare to take advantage of the market, organizations must have within their ranks creative employees with abilities to transform information to product and process innovations. As the 21st century industry is driven by automation-led innovation, executives and professionals have also highlighted that soft skills such as employees' creative abilities have become a necessity now more than ever before.

Despite the growing scholarly interest in service innovation research (for review and meta-analysis see [6,13-15]), this relatively burgeoning stream of inquiry remains understudied, and there are several calls for extending the extant state of literature, especially pertaining employee IB [3,7]. Limited research has investigated the determinants of employee innovative behaviors in the hospitality sector to date [3,16]. For instance, Edghiem and Mouzughi [17] observed a causal link between pro-encounter and encounter dependent-knowledge and service employees' innovative behaviors. Kim, Karatepe, and Lee [18] demonstrated that perceived psychological contract breach mitigated hotel employees' service innovative behaviors. Bani-Melhem et al. [2] reported a positive effect of workplace happiness and co-worker support on employee IB, while other scholars proposed workplace spirituality and perceived organizational support [19], knowledge-sharing [20], solidarity and harmonization as dimension of customer employee exchange [21], ethical leadership, and leader-member exchange [22,23] as significant predictors. Despite some proven or anticipated outcomes, the consequences of IB are generally overlooked in the service innovation research.

Against this backdrop and under the framework of the resource-based view (RBV) [24] and the job demands-resources (JD-R) model [25], this study proposes an original model testing the mediated effect of high-performance work practices (HPWP) on competitive advantage (CA) via IB. Furthermore, this model also examines employee creativity traits moderating the impact of HPWP on IB and CA.

\section{Contribution of the Study}

This study extends the hospitality, service innovation, and human resources management's current body of knowledge in the following ways. First, scholars have discussed that developing and implementing human resources management (HRM) practices are decisive [26] and enhances employees' pro-innovative work behaviors, e.g., [26-29]. Among the extant research in this stream, a majority were carried out in higher education institutions [30,31], manufacturing [32,33], financial service [27,30], small and medium enterprises (SMEs) [34], and healthcare [35] firms. Only Dhar in 2015 [9], Ansari, Siddiqui, and Farrukh in 2018 [36], and Jaiswal and Tyagi in 2019 [37] empirically examined relationships between HPWPs and innovative behaviors in the hospitality sector in India and Pakistan. Despite their notable contributions, these studies fell within the findings of recent systematic reviews [3,7], highlighting that scholars consider IB as the endpoint variable. 
In response to these reviews, van Esch, Wei, and Chiang [38] proposed HPWP as a predictor of employees' competencies (technical, behavioral, and business competencies) and subsequently of firm financial performance. All measures were carried out at the top management level (CEOs and CFOs), and CEOs rated IT department employees' competences. In contrast to this research, our study embodies employees' perspectives of their organization HPWPs and managers' perspective of employee's innovative behaviors with a focus on frontline employees, who are at the core of service businesses' strategy and performances and interact intensively with customers.

Second, the strategic management literature indicates that innovation forerunner businesses catalyze their performance and, subsequently, CA. This study examines the effect of IB on CA, and concurrently, investigates IB as a mediator between HPWP and firm CA. The findings advance the extant literature by addressing several gaps. Bäckström and Bengtsson in 2019 [7] and Li and Hsu in 2016 [3] noted the dearth of research on outcomes of IB, as most scholars considered it as their endpoint variable. Moreover, in contrast to firm (financial, service, operational) performance, empirical studies have paid lesser attention to and verified the allegedly positive effect of innovation on CA [39,40], especially in the hospitality sector. Unraveling the importance of employee IB to CA is both theoretically and practically valuable. Considering that employee IB can be potentially more prominent when the end-product is, in essence, homogeneous like in the hospitality sector, its incidence on CA through customer value attribution, satisfaction, and retention can no longer be neglected.

Third, this study goes beyond the relationship mentioned above by investigating the moderating effect of creativity. Seeck and Diehl in 2017 [41] indicated in their HRM innovation literature review that researchers had overlooked potential moderators of the HRM innovation relationship and only eight studies engaged in this examination. Employee creativity is often coined as the precursor of innovation [42] because it implicates idiosyncratic cognitive processes that induce idea creation [39]. The creative-thinking ability is accordingly different across individuals, and this study examines when it influences employee IB and CA in the specific context of HPWP implementation and discusses when it beneficiates the organization.

The current study is conducted in North Cyprus 4- and 5-star hotels that employ mostly Turkish and Turkish Cypriot employees and managers. Various studies [43-45] demonstrated that innovation capability and innovative behaviors in organizations play critical roles in the Turkish culture. As such, the proposed model tests for the first time the effect of HPWPs on employee IB in the hybrid Mediterranean and Turkish cultural sphere.

\section{Theoretical Framework and Hypotheses Development}

\subsection{HPWPs, Innovative Behavior, and Competitive Advantage}

A framework of the resource-based view (RBV) [24,46] posits that valuable, rare, inimitable, and non-substitutable (VRIN) resources and capabilities enable a firm to sustain its CA. Barney [24] and Snell, Shadur, and Wright [47] argued that firm assets include physical and intangible organizational capital that comprises human capital. In contrast to easy-to-copy physical assets, firms must nurture their human capital and get it as much tacit, heterogeneous, and immobile as possible. Later, Barney and Wright [48] proposed a VRIO (value, rareness, imitability, and organization) framework that sheds more light on the role of human resources functions in achieving sustained CA. Performing that not only prevents competitors from copying or acquiring similar human capital, but also will dramatically propel the focal firm to preserve a significant competitive edge. To this end, industry leaders customarily promote a bunch of work practices that have become known as HPWPs and involve aggregating a spectrum of HR strategies into a model of best practices [49]. In their recent research, Hamadamin and Atan [50] confirmed that strategic HRM practices are a significant and positive antecedent of sustainable competitive advantage.

HPWPs represent a set of HRM practices that enable the acquisition of unique intellectual capital (e.g., knowledge, skills, and ability-KSA), as well as the development of social capital and application 
of abilities enhancing practices [51]. Core indicators of HRM have been highlighted as inherent to HPWPs. For instance, selective staffing and internal training and development are necessary for companies to select the best combination of available human capital and later on adapt and improve for heightened organizational capabilities, productivity, and profit growth [52,53]. Teamwork is another indicator requiring information sharing and collaboration between employees and is critical to building necessary connections that will improve the social capital of the firm [54]. Moreover, an appropriate rewards system and contextual empowerment make it possible to revamp the morale, motivation, and self-confidence of employees to display desirable work outcomes [47].

Chowhan [55] proposed that training provides knowledge, skills improvement, and learning that foster employee unique tacit, inimitable human capital, which in turn develop potential creative capacities, and thereby innovative work outcomes. The selective staffing process includes employee recruitment from an adequate pool of candidates and selection of the most suitable ones. De Winne and Sels [15] found that a broad range of HRM practices, including the selection of people with high human capital, positively influenced innovative outputs. Furthermore, innovative reward schemes for new or enhanced process or outcomes can frame a work environment that acknowledges and compensate innovative initiatives and inspire employee innovative orientation. For instance, Curran and Walsworth [56] revealed that group motivator pay, benefit-sharing, and employee advantages have positive and considerable impacts on innovation. Overall, scholars have demonstrated that HPWPs dimensions oriented towards encouraging pro-innovative attitudes and behaviors are considerable indicators of innovative outcomes $[28,57,58]$ such as employee IB $[9,36]$ in the hospitality sector.

Furthermore, Chatzoglou and Chatzoudes [59] supported that [process and product] innovation has a positive impact on organizational CA. While the study focused on manufacturing firms, Liu [60] uncovered an indirect effect of employee IB on competitive advantage via human capital with a sample of various levels of department managers in China-based hotels. Moreover, Connolly and McGing [49] analyzed the relationship between HPWPs and competitive advantage in the Irish hospitality industry. They attempted to uncover the extent of adoption of these practices in selected 3- to 5-star Dublin-based hotels, with specific emphasis on employees' empowerment and participation. They concluded that customers growing demand for high-quality products and services, as well as discernment, constituted a call for hotels to address the implementations of these practices to remain competitive.

In light of the paragraphs above and the relevant literature perusal, this study suggests that hotels that adopt and implement HPWPs can attain a CA, thanks to their exclusive human resources. More importantly, though, the CA attainment and sustainability impetus resides in the value generated by employees' IB. That is, ad hoc HPWPs provide the framework that shapes unique human capital and create a proactive-oriented work environment that facilitates the expression of employees' innovative potential. In return, employees exhibiting IB can beget superior utility for both customers and the organization, which subsequently will conspicuously stand out a notch ahead of competitors. Thus, this study proposes the following hypothesis:

Hypothesis 1 (H1). Employee IB mediates the effect of HPWP on CA.

\subsection{The Moderating Role of Employee Creativity}

Employee creativity refers to the generation of novel ideas or solutions to problems by employees. The literature suggests that creativity significantly influences organizational innovation $[42,61]$ or firm performance [62]. In line with the RBV, creativity is an intangible, rare, inimitable, non-substitutable resource that can be a valuable source of competitiveness and gaining a sustainable CA for organizations $[24,63,64]$. Scholars have discussed that individual creativity is at the confluence of contextual and idiosyncratic factors [40,65]. For instance, Amabile and Pratt [66] and Liu et al. [67] contended that personality, cognitive processes, intrinsic and prosocial motivation, self-efficacy, affect, and sense of meaningful work are predictors of individual creativity. All these factors differ across individuals in this sense that some likely display more of those factors more than others do. 
From this premise, creativity will likely vary from person to person, despite the dynamics of the surrounding contextual factors. Specifically, regardless of whether or not elements of the workplace environment encourage creativity, an employee exhibiting a greater extent of these individual creativity-enhancing characteristics would also be prone to show higher creative abilities. Ultimately, service organizations that succeed in securing, retaining, and managing the services of highly creative individuals would be strategically better off than their counterparts with employees with lesser creative abilities. Subsequently, since creativity is a source of firms' CA and concurrently varies from one individual to another, this study predicts that it will strengthen the positive effect of HPWPs on CA, and proposes the following hypothesis:

Hypothesis 2 (H2). Employee Creativity moderates the effect of HPWP on CA. This relationship is stronger when employee creativity is greater.

Creativity and IB are usually associated with each other because most scholars view them as the front and endpoint of a multi-stage process, respectively [3], or simply as relatively similar [68]. Despite this widely accepted view and the interactionist model of creativity [65], there is a growing body of scholars opposing such a simplistic view of the link between the two concepts. They highlight a more complex relationship and argue that creativity fundamentally differs from innovation. For instance, Sarooghi, Libaers, and Burkemper [69] adopted an ambidexterity perspective to highlight the dichotomy between idea generation (creativity) and their implementation (innovation), which is often subject to dilemma, tensions, contradictions, and paradoxes in organizations. Moreover, innovation relies on interpersonal social processes rather than intrapersonal cognitive processes [70].

One can reasonably argue, inspired by the premises of the [dynamic] componential model of individual creativity $[42,66]$, that IB is contingent on the individual level of creative cognitive abilities, domain-relevant skills, motivation, and work meaning. More creative employees usually would rely on their own [abilities] if or when their work environment is restrictive, non-conducive, or idle toward creativity. In this case, consistent with the JD-R model [25,71], creativity will stand as an employee personal resource that will be handy in exhibiting IB. The magnitude and frequency of IB would be even higher when a creative employee benefits from conducive organizational factors such as HPWPs. That is, the more prominent the individual characteristics promoting creativity, the higher the positive influence of HPWPs on employee IB. From this rationale, this study proposes that:

Hypothesis 3 (H3). Employee Creativity moderates the effect of HPWP on IB. This relationship is stronger when employee creativity is greater.

In line with the previous hypotheses, we also propose that the indirect effect of HPWP on CA through IB would differ across low versus the high level of employee creativity. Therefore, the following hypothesis is developed:

Hypothesis 4 (H4). Employee creativity moderates the indirect effect of HPWP on CA via IB.

The conceptual model is shown in Figure 1. The model suggests that innovative work behavior would mediate the relationship between HPWP and CA. In addition, the model shows that, Employee creativity moderates the effect of HPWP on CA and IB. Finally, the model infers that employee creativity moderates the indirect effect of HPWP on CA via IB. 


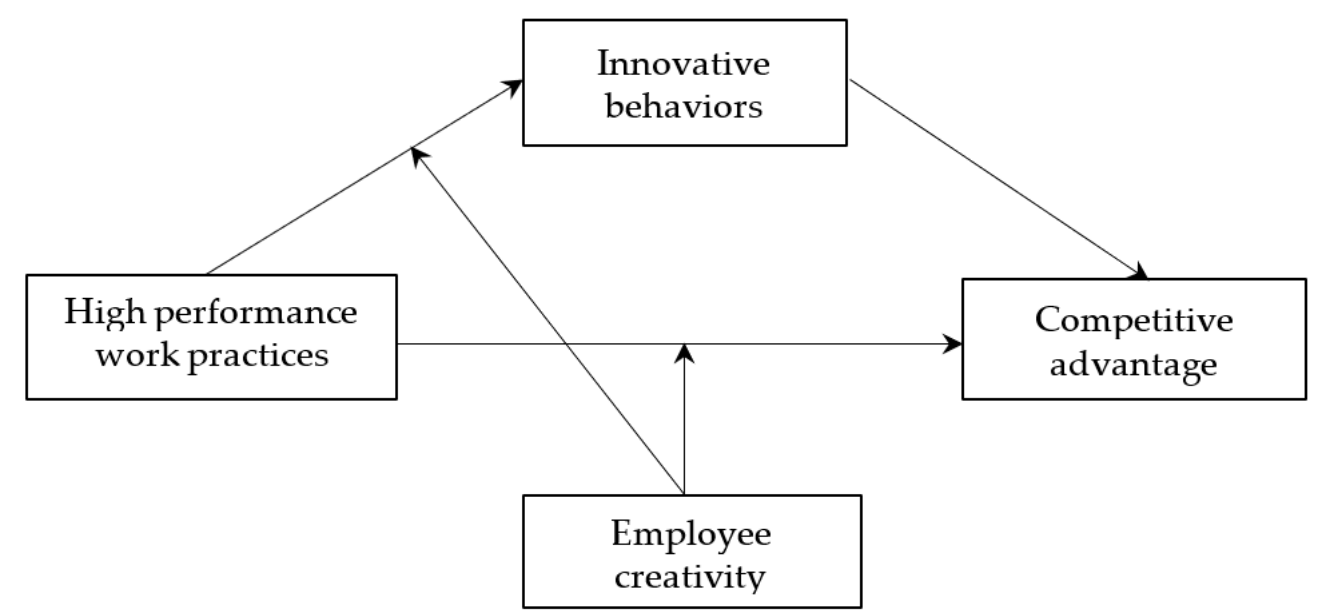

Figure 1. Research model.

\section{Method}

\subsection{Sample and Procedure}

The human resources management literature in the hospitality recommended that upscale star-level hotels give vital understanding for investigations of hotels' human resource (HR) administration and mirror the phenomena of hospitality settings development [60]. This study selected sample respondents from 4- and 5-star hotels. Questionnaires were distributed to 405 frontline employees (front office, food and beverage, housekeeping, guest relations, sales, and marketing) and immediate managers. Employees filled out the questionnaire with items related to HPWPs (empowerment, training, rewards, selective staffing, and teamwork), while managers filled out those with items related to the manager's perspective of employees' creativity and innovative behavior, and competitive advantage. A total of 323 usable questionnaires were returned, giving a response rate of $79.75 \%$.

Before the data collection process, the authors obtained permission to proceed with the study from their institution's ethics committee. Various procedural remedies were utilized to minimize the probability of common method variance, as recommended by Podsakoff, MacKenzie, and Podsakoff [72]. First, a cover letter was provided to express the aim of the research, to ensure the anonymity and confidentiality of data usage, and specify that there were no right or wrong responses. Second, respondents were told that participation was voluntary. Third, data were obtained from employees and their direct manager in a two-week time-lagged period, respectively. All questionnaires were prepared in English, then translated into Turkish, then back-translated into English by academicians proficient in both languages [73].

\subsection{Measurements}

High-Performance Work Practices (employees rated): HPWP was operationalized with five sub-dimensions: Training, empowerment, selective staffing, rewards, and teamwork. A six-item scale was obtained from Boshoff and Allen [74] to measure training. The empowerment subscale contained five items adapted from Hayes [75]. The rewards dimension was measured using five items from Bosshoff and Allen [74]. Selective staffing was measured with a four-item scale from Sun, Aryee, and Law [76]. Teamwork was measured with a five-item scale from Coyle-Shapiro and Morrow [77]. Responses were filled on five-point Likert-type scales ranging from 5 (strongly agree) to 1 (strongly disagree).

Employees' Creativity (manager rated): Employees' creativity was measured with George and Zhou's [78] 13 items on a 5-point Likert scale, from (1) not at all characteristic to (5) extremely characteristic.

Innovative Behaviors (manager rated): Six items adapted from $\mathrm{Hu}, \mathrm{Horng}$, and Sun [79] were used to measure the innovative behaviors on a 7-point scale from 1 (strongly disagree) to 7 (strongly agree). 
Competitive advantage (manager rated): Competitive advantage was measured using four items that were utilized by $\mathrm{Wu}$ and $\mathrm{Chen} \mathrm{[80]} \mathrm{and} \mathrm{rated} \mathrm{on} \mathrm{a} \mathrm{7-point} \mathrm{scale} \mathrm{from} 1$ (strongly disagree) to 7 (strongly agree). The measurement items are provided in Appendix A, Table A1.

\subsection{Data Analysis}

We used SPSS Amos to conduct a confirmatory factor analysis (CFA) and assess the reliability, convergent, and discriminant validity of the construct. Model goodness of fit was estimated using the normed chi-square ( $\chi^{2} / \mathrm{df}$ ), IFI (incremental fit index), CFI (comparative fit index), RMSEA (root mean square error approximation), and SRMR (standardized root mean square) [81]. Finally, the PROCESS macro was used to test the proposed hypotheses.

\section{Results}

\subsection{Measurement Model for HPWP}

The first-order five-factor measurement model (empowerment, training, rewards, selective staffing, and teamwork) was examined. Two items from empowerment and selective staffing, respectively, were dropped due to standardized loadings less than 0.40 . The revised five-factor measurement model after deletion demonstrated a good fit $\left(\chi^{2}=559.506, d f=195, p<0.001 ; \chi^{2} / d f=2.87 ;\right.$ SRMR $=0.067$; RMSEA $(90 \% \mathrm{CI})=0.076(0.069 ; 0.084) ; \mathrm{CFI}=0.913 ; \mathrm{IFI}=0.914)$. All standardized loadings were significant $(p<0.01)$ and above 0.50 [82], ranging from 0.591 to 0.919 , as depicted in Table 1 . The average variance extracted (AVE), composite reliability (CR), and Cronbach's alphas for each construct were respectively above $0.50,0.70$, and $0.70[83,84]$. Overall, these results supported the convergent validity and reliability of the sub-construct. The discriminant validity (see Table 2) was also supported as the square root of each construct's AVE was greater than the correlations between constructs [83].

Table 1. Confirmatory factor analysis (CFA) results of high-performance work practice (HPWP).

\begin{tabular}{|c|c|c|c|c|c|}
\hline & Standardized Loadings & $t$-Values & Composite Reliability & Alpha & AVE \\
\hline Empowerment & & & 0.753 & 0.71 & 0.505 \\
\hline E1 & 0.671 & Fixed & - & - & \\
\hline E2 & - & - & - & - & \\
\hline E3 & 0.69 & 8.199 & - & - & \\
\hline E4 & 0.767 & 8.922 & - & - & \\
\hline E5 & - & - & - & - & \\
\hline Training & & & 0.879 & 0.874 & 0.552 \\
\hline $\mathrm{T} 1$ & 0.591 & Fixed & - & - & \\
\hline $\mathrm{T} 2$ & 0.718 & 9.947 & - & - & \\
\hline $\mathrm{T} 3$ & 0.802 & 10.967 & - & - & \\
\hline $\mathrm{T} 4$ & 0.816 & 11.079 & - & - & \\
\hline T5 & 0.878 & 11.431 & - & - & \\
\hline T6 & 0.606 & 8.966 & - & - & \\
\hline Rewards & & & 0.899 & 0.90 & 0.644 \\
\hline RWD1 & 0.695 & Fixed & - & - & \\
\hline RWD2 & 0.68 & 13.27 & - & - & \\
\hline RWD3 & 0.919 & 15.052 & - & - & \\
\hline RWD4 & 0.849 & 14.125 & - & - & \\
\hline RWD5 & 0.843 & 14.028 & - & - & \\
\hline Selective staffing & & & 0.842 & 0.83 & 0.644 \\
\hline SS1 & - & - & - & - & \\
\hline SS2 & 0.634 & Fixed & - & - & \\
\hline SS3 & 0.899 & 12.298 & - & - & \\
\hline SS4 & 0.85 & 12.071 & - & - & \\
\hline Teamwork & & & 0.884 & 0.88 & 0.61 \\
\hline TW1 & 0.693 & Fixed & - & - & \\
\hline TW2 & 0.899 & 14.595 & - & - & \\
\hline TW3 & 0.862 & 14.131 & - & - & \\
\hline TW4 & 0.591 & 9.952 & - & - & \\
\hline TW5 & 0.816 & 13.462 & - & - & \\
\hline
\end{tabular}

Notes. Model fit statistics: $\chi^{2}=559.506, d f=195, p<0.001 ; \chi^{2} / d f=2.87 ;$ SRMR $=0.067 ;$ RMSEA $(90 \%$ CI $)=0.076$ $(0.069 ; 0.084) ; \mathrm{CFI}=0.913 ; \mathrm{IFI}=0.914$. All loadings are significant at $p<0.001$. AVE: average variance extracted; (-) dropped during confirmatory factor analysis. 
Table 2. Discriminant validity test for HPWP.

\begin{tabular}{cccccc}
\hline & $\mathbf{1}$ & $\mathbf{2}$ & $\mathbf{3}$ & $\mathbf{4}$ & $\mathbf{5}$ \\
\hline 1. Empowerment & $\mathbf{0 . 7 1 1}$ & - & - & - & - \\
2. Training & 0.496 & $\mathbf{0 . 7 4 3}$ & - & - & - \\
3. Rewards & 0.599 & 0.444 & $\mathbf{0 . 8 0 3}$ & - & - \\
4. Selective staffing & 0.446 & 0.527 & 0.543 & $\mathbf{0 . 8 0 3}$ & - \\
5. Teamwork & 0.383 & 0.351 & 0.319 & 0.530 & $\mathbf{0 . 7 8 1}$ \\
\hline
\end{tabular}

Notes: Entries in bold on the diagonal are the square roots of constructs AVEs. Below the diagonal are construct correlations, all significant at $p<0.001$.

Second, a second-order CFA was employed to test HPWP as a second-order construct with its corresponding five first-order factors. The model fit indices were as follows: $\chi^{2}=582.702, d f=200$, $p<0.001 ; \chi^{2} / d f=2.91 ;$ SRMR $=0.074 ;$ RMSEA $(90 \% \mathrm{CI})=0.077(0.070 ; 0.084]$; CFI $=0.909 ;$ IFI $=0.909$. Previous literature $[85,86]$ argued that a model holding a second-order structure could never produce a better model fit than a specified first-order correlated model. However, it can satisfactorily be an appealing alternative that rivals the first-order correlated model [85]. A second-order factor is deemed to be appropriate if the target coefficient $(T)$-a comparative coefficient of the ratio of the first-order model chi-square to the second-order model chi-square-approaches 1.0 [86]. The T index obtained was 0.96 (559.506/582.702), suggesting that the second-order factor (HPWP) is adequate for further use and hypothesis testing.

\subsection{Overall Measurement Model}

A CFA of the full measurement model, with EC, IB, CA, and HPWP, was performed, and three items of EC-EC1, EC3, and EC6-were dropped during the CFA due to loadings below 0.50 and correlation measurement errors. The results showed a relative acceptable fit: $\chi^{2}=2194.729, d f=776$, $p<0.001 ; \chi^{2} / d f=2.83 ;$ SRMR $=0.076$; RMSEA $(90 \% \mathrm{CI})=0.075(0.072 ; 0.079) ; \mathrm{CFI}=0.856 ;$ IFI $=0.857$. Although the CFI and IFI were marginally below 0.90, researchers (e.g., Davis-Becker, Peterson, and Fischer [87]; Iacobucci [88]) have argued that non-parsimonious models may still fit the data well when CFI is marginally below 0.90 while other indices are satisfactory like evidenced in recent studies (e.g., [89]).

Table 3 illustrates that the AVEs of EC, IB, CA, and HPWP were respectively 0.583, 0.55, 0.77, and 0.47. Prior research has indicated that an AVE below 0.50 is still adequate if the composite reliability is satisfactory $[83,90]$, as demonstrated by previous empirical findings in the service research $[18,90]$.

The composite reliability scores and alpha coefficients ranged respectively from 0.817 to 0.933 , and 0.88 to 0.93 , which fell beyond the conventional cut-off of $0.70[83,84]$. The standardized loadings of each construct exceeded 0.50 [82] and ranged from 0.565 to 0.969 and were all significant at $p<0.01$. Thus, the above indications provided sufficient support for convergent validity and reliability. Further, the results presented in Table 4 showed that the intercorrelations between the constructs were lower than the square root of each respective construct's AVE [83], which therefore provided evidence for discriminant validity. 
Table 3. CFA results of overall model.

\begin{tabular}{|c|c|c|c|c|c|}
\hline & Standardized Loadings & $t$-Values & Composite Reliability & Alpha & AVE \\
\hline HPWP & & & 0.817 & 0.91 & 0.475 \\
\hline Empowerment & 0.714 & Fixed & - & - & - \\
\hline Training & 0.663 & 6.558 & - & - & - \\
\hline Rewards & 0.722 & 7.218 & - & - & - \\
\hline Selective staffing & 0.765 & 6.983 & - & - & - \\
\hline Teamwork & 0.565 & 6.403 & - & - & - \\
\hline Employee creativity & & & 0.933 & 0.93 & 0.583 \\
\hline EC1 & - & - & - & - & - \\
\hline EC2 & 0.707 & Fixed & - & - & - \\
\hline EC3 & - & - & - & - & - \\
\hline EC4 & 0.72 & 12.459 & - & - & - \\
\hline EC5 & 0.793 & 13.29 & - & - & - \\
\hline EC5 & - & - & - & - & - \\
\hline EC7 & 0.746 & 12.725 & - & - & - \\
\hline EC8 & 0.736 & 12.734 & - & - & - \\
\hline EC9 & 0.69 & 11.02 & - & - & - \\
\hline EC10 & 0.804 & 13.971 & - & - & - \\
\hline EC11 & 0.869 & 14.722 & - & - & - \\
\hline EC12 & 0.812 & 13.891 & - & - & - \\
\hline $\mathrm{EC} 13$ & 0.739 & 12.657 & - & - & - \\
\hline Innovative behavior & & & 0.879 & 0.88 & 0.55 \\
\hline IB1 & 0.739 & Fixed & - & - & - \\
\hline IB2 & 0.73 & 13.005 & - & - & - \\
\hline IB3 & 0.881 & 14.995 & - & - & - \\
\hline IB4 & 0.731 & 13.029 & - & - & - \\
\hline IB5 & 0.639 & 10.64 & - & - & - \\
\hline IB6 & 0.708 & 11.798 & - & - & - \\
\hline Competitive advantage & & & 0.931 & 0.93 & 0.771 \\
\hline CA1 & 0.86 & Fixed & - & - & - \\
\hline CA2 & 0.969 & 13.233 & - & - & - \\
\hline CA3 & 0.897 & 10.03 & - & - & - \\
\hline CA4 & 0.775 & 7.019 & - & - & - \\
\hline
\end{tabular}

Notes: Model fit statistics: $\chi^{2}=2194.729, d f=776, p=0.000 ; \chi^{2} / d f=2.83$; SRMR $=0.076$; RMSEA $(90 \%$ CI $)=0.075$ $(0.072 ; 0.079) ; \mathrm{CFI}=0.856$; IFI $=0.857$. All loadings are significant at $p<0.001$. (-) dropped during confirmatory factor analysis.

Table 4. Descriptive statistics and discriminant validity overall model.

\begin{tabular}{ccccc}
\hline & $\mathbf{1}$ & $\mathbf{2}$ & $\mathbf{3}$ & $\mathbf{4}$ \\
\hline 1. Employee creativity & $\mathbf{0 . 7 6 3}$ & - & - & - \\
2. Innovative behavior & $0.537^{* * *}$ & $\mathbf{0 . 7 4 1}$ & - & - \\
3. Competitive advantage & $0.316^{* * *}$ & $0.382^{* * *}$ & $\mathbf{0 . 8 7 8}$ & - \\
4. HPWP & 0.037 & $0.244^{* * *}$ & $0.107+$ & $\mathbf{0 . 6 8 9}$ \\
Mean & 3.63 & 4.79 & 5.70 & 3.35 \\
SD & 0.75 & 1.15 & 1.29 & 0.69 \\
\hline
\end{tabular}

Notes: Entries in bold on the diagonal are the square roots of constructs AVEs. Below the diagonal are construct correlations; $+p<0.10,{ }^{*} p<0.05,{ }^{* *} p<0.01,{ }^{* * *} p<0.001$.

\subsection{Hypotheses Testing}

H1 predicted that innovative behaviors would mediate the effect of HPWP on CA. The SPSS-built macro PROCESS [91] (Model 4) was used to estimate the parameters for the mediation test, with a 95\% bias-corrected confidence interval (BC CI) generated from 10,000 bootstrapped samples. The mediated model showed an overall significance $\left(F(2320)=19.83, p<0.001, R^{2}=0.11\right)$; specifically, HPWP predicted IB $(b=0.29, p<0.01)$, which in turn predicted CA $(b=0.36, p<0.001)$. However, the direct path between HPWP and CA was not significant $(b=0.06, p=0.52)$ when controlled for IB, while the 
indirect effect estimate was significant $(a b=0.10, S E=0.05, C I=0.03-0.21)$. These results sufficed to support H1.

Next, $\mathrm{H} 2, \mathrm{H} 3$, and $\mathrm{H} 4$ were tested using PROCESS model 8 with a 95\% BC CI bootstrap sample of 10,000. Table 5 exhibits the results of the moderated mediation analysis. H2 found support because EC significantly moderated the direct effect of HPWP on CA $(b=-0.77, p<0.001)$, as displayed on the interaction plot (Figure 2). The interaction between HPWP and EC on IB was not significant $(b=0.08$, $p=0.48$ ). A scrutiny of the conditional effect results, however, shows that the direct effect of HPWP on IB at low level of EC is insignificant $\left(b_{\text {low }}=0.19, p=0.23, \mathrm{CI}=-0.13-0.51\right)$, while it is significant at medium $\left(b_{\text {med }}=0.25, p<0.01, \mathrm{CI}=0.06-0.44\right)$ and high levels $\left(b_{\text {high }}=0.31, p<0.01, \mathrm{CI}=0.10-0.52\right)$ of EC. Therefore, H3 was partially supported. Further, the conditional indirect effect results in Table 5 disclosed that the CI of two out of the three indirect effects level of EC was significantly different from zero. Thus, $\mathrm{H} 4$ was supported.

Multicollinearity was not an issue in this study because the variance inflation factors (VIFs) of each predicting variable was less than 3. Harman's single factor test revealed that the first factor accounted for $19.24 \%$, which is far less than $50 \%$. Therefore, common method bias was not deemed a severe threat to this study.

Table 5. Conditional process analysis.

\begin{tabular}{|c|c|c|c|c|}
\hline & $b$ & $S E$ & $t$ & $p$ \\
\hline \multicolumn{5}{|c|}{ Mediator model (Outcome: innovative behavior) } \\
\hline Constant & 4.79 & 0.05 & 85.89 & $<0.001$ \\
\hline HPWP & 0.25 & 0.08 & 3.06 & $<0.01$ \\
\hline Employee creativity & 0.73 & 0.07 & 9.66 & $<0.001$ \\
\hline HPWP x Employee creativity & 0.08 & 0.11 & 0.71 & 0.48 \\
\hline \multicolumn{5}{|c|}{ Dependent variable model (Outcome: competitive advantage) } \\
\hline Constant & 4.33 & 0.31 & 13.81 & $<0.001$ \\
\hline HPWP & 0.15 & 0.09 & 1.55 & 0.12 \\
\hline Innovative behavior & 0.29 & 0.06 & 4.52 & $<0.001$ \\
\hline Employee creativity & 0.18 & 0.09 & 1.86 & 0.06 \\
\hline \multirow[t]{2}{*}{ HPWP x Employee creativity } & -0.77 & 0.12 & -6.22 & $<0.001$ \\
\hline & $b$ & $S E$ & $t$ & $p$ \\
\hline \multicolumn{5}{|c|}{ Conditional direct effect at employee creativity $=M \pm 1 S D$} \\
\hline$M-1 S D(2.88)$ & 0.73 & 0.14 & 5.19 & $<0.001$ \\
\hline $\mathrm{M}(3.63)$ & 0.15 & 0.09 & 1.55 & 0.12 \\
\hline $\mathrm{M}+1 \mathrm{SD}(4.38)$ & -0.44 & 0.13 & -3.48 & $<0.001$ \\
\hline \multicolumn{5}{|c|}{ Conditional indirect effect at employee creativity $=M \pm 1 S D$} \\
\hline & Value & Boot SE & LLCI & ULCI \\
\hline$M-1 S D(2.88)$ & 0.05 & 0.05 & -0.03 & 0.16 \\
\hline $\mathrm{M}(3.63)$ & 0.07 & 0.03 & 0.02 & 0.15 \\
\hline $\mathrm{M}+1 \mathrm{SD}(4.38)$ & 0.09 & 0.04 & 0.02 & 0.17 \\
\hline
\end{tabular}

Note. $\mathrm{N}=323$. Unstandardized regression coefficients are reported. Bootstrap sample size $=10,000 . \mathrm{LL}=$ lower limit, $\mathrm{CI}=$ confidence interval, $\mathrm{UL}=$ upper limit. 


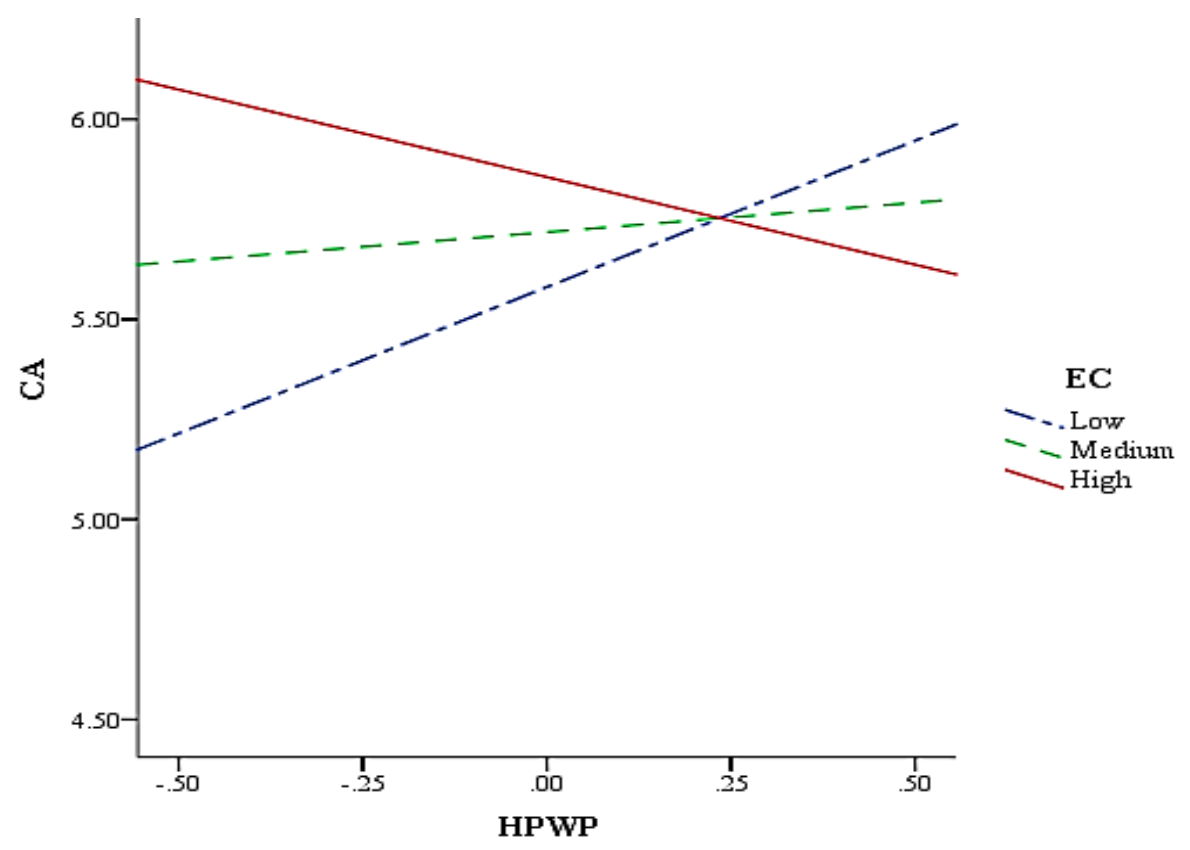

Figure 2. Employee creativity as a moderator of the effect of HPWP on competitive advantage.

\section{Discussion}

The paramount aim of this study was to test a moderated mediation model of employee creativity and innovative behaviors on the HPWP competitive advantage nexus. Specifically, the study examined the indirect effect of IB on the causal relationship between HPWP and CA, and also the moderating role of EC on this indirect effect. The results yielded several insightful theoretical and managerial implications, which are discussed hereafter.

\subsection{Theoretical Implications}

The current study provides several contributions to the body of knowledge. First, we proposed and found support for an original conceptual framework underscoring HPWPs as indirectly predicting competitive advantage via innovative behaviors. In line with previous scholars (e.g., Fu, Flood, Bosak, Rousseau, Morris, and O'Regan [92]), this study confirms that service firms achieve superior CA not merely by HPWPs per se, instead, by the actual capital resources that such practices generate. Indubitably under fierce competitive and dynamic environmental conditions, the implementation of HPWPs and the ownership of derived intellectual capital are meaningless to sustain CA if the organization fails to build innovative capacity [92,93]. Accordingly, our study confirms the sentiment that effective HPWPs are essential in motivating employees' pro-innovative behaviors and actions $[28,58]$ and corroborate with similar findings $[29,33,92]$.

Furthermore, our findings support the widely accepted ideas, but scanty empirical evidence of the effect of organizational innovation on CA. For instance, Chatzoglou and Chatzoudes [59] found that a higher level of innovation in terms of new products/services or business processes leads to a better CA performance. We found that IB positively relates to CA. We argue that employees' IBs instead consist of a more practical assessment of innovation for service firms with high customer physical interaction propensity (e.g., hotels, airline carriers). Due to the provided services quasi similarities, any firm will demarcate itself from competitors in terms of its employees' IBs towards service performance, delivery, and experience. In synopsis, the implementation of HPWPs grants service organizations CA only when they yield a manifest and value-adding set of employees IB.

Second, we proposed that creativity would strengthen the effect of HPWP on IB and CA, following the extant literature demonstrating creativity as a viable predictor of innovative outcomes and henceforth organizational competitiveness [94,95]. Interestingly, our results paradoxically suggested 
that creativity mitigated the positive effect of HPWP on CA. Specifically, the implementation of HPWPs is promising for sustained CA with less creative employees, who are comfortable with predetermined and conventional procedures. Inversely, highly creative employees suffer from a maladaptation in the workplace due to the restraints of their creative expression, which can result in frustration with the job, the manager, and colleagues. While this finding contrasts with what the literature infers, innovation and creativity research reviews conceded the existence of conflicting empirical findings in the current state of science [40]. Precisely, the success occurrence of innovation in the hospitality industry is somewhat small [10], due to the risk associated with creativity/innovation characterized by individuals/organizations' deviation from conventional practices, which orient them to change, think, and act differently [40]. However, the fear of the change embedded with risk-taking, uncertainty, and potential for failure can constrain managers to only refer to their limited knowledge and experience [10]. Consequently, they will restrict and create barriers to creative individuals, hence underexploiting their employees' creative potential [65] and undermining their competitive advantage. Furthermore, the dynamic capability framework [96] for sustained competitive advantage suggests that not solely the ownership of unique and inimitable resources, but also the combination, reconfiguration, and adaptation of available assets can grant an organization a competitive edge. The salience of the management risk avoidance of and constraint towards creativity can be even prominent in high power distance and high uncertainty avoidance culture such as the Turkish one. Hofstede Insights [97] scored the Turkish culture as 85 and 66 over 100 in uncertainty avoidance (UA) and power distance (PD), respectively. High UA reflects high sensitivity towards ambiguity and consistent reliance on set of rules to curtail anxiety and control the unknown. High PD reflects hierarchy and power centralization where " $(\ldots)$ managers rely on their bosses and on rules, and employees expect to be told what to do. Control is expected and attitude towards managers is formal". In North Cyprus hotels, more than $74 \%$ of managers are Turkish citizens $[98,99]$. Overall, this study contributes to the workplace creativity literature by underscoring the circumstantial hindering effect of creativity on firm competitive advantage.

Thirdly, as it stood out and owing to a more liberal interpretation, only a relatively greater sense of creativity may reinforce the role of HPWP on IB. To this extent, the HPWP-laid human capital finds its merits better under circumstances of acute creative cognitive capabilities. This is consistent with the job demand resources model's [25] articulation that personal resources such as creativity would contribute to enriching individual work performance. In this vein, creativity will be of top importance in an organization aiming to build and sustain a competitive advantage. As mentioned earlier, HPWPs are a distal predictor of CA and finds its significance via employee IBs. This relationship is strengthened when the availability of a creative labor pool becomes prominent.

\subsection{Practical Implications}

The findings of this study also address hospitality managers, with particular foci to those in North Cyprus hotels in several ways. Firstly, the need for hotels to implement HPWPs is critical for their performance and survival in the stiffly competitive and dynamic environment in which they operate. Undeniably, how well they can manage to nurture and yield innovative work behaviors from their workforce is essential to differentiate their service offered from competitors. Most hiring determinants in hotels usually revolve around pro-interpersonal and group-oriented behaviors, as well as job skills and personal career orientation [100]. It would be fair to say these factors rather depict the need to hire "good soldiers", employees that can fit in their unit and get along with colleagues and the supervisors, while diligently and unquestionably accomplishing the tasks assigned to them. This study suggests that hiring managers or professionals should equally consider orienting their needs into the creative abilities of their candidates, how they come up with complex issues or situations, or apply some positive changes to a given task.

Secondly, this paper also addresses managers about the way they can consider actual creative employees and get the best out of this tacit resource. We discussed in earlier paragraphs how power 
distance and uncertainty avoidance could hamper the expression of creativity and makes it a hindrance to the organization. To this end, managers and executives of 4- and 5-star hotels, but also regular hotels operating in high power distance and uncertainty avoidance cultural spheres, may consider the option of undergoing training on how to how to dissociate their cultural attributions and the demands of business competition. Precisely, such training must enable them to manage creative employees by seriously considering their opinions, advice, and suggestions. In this vein, they must accept to leap forward into the ambiguity raised by the outcomes of innovative ideas and behaviors.

\section{Limitations and Future Directions}

Based on the resource-based view and job demands resources model, the present study developed an original conceptual framework that investigated the impact of HPWP on employee innovative behaviors and competitive advantage. The results suggest that IB fully mediates the relationship between HPWP and competitive advantage. Although this study makes several critical contributions, it also has some limitations and further suggestions for hospitality research. First, this research adopted a cross-sectional design. Future research could explain the hypothesized model with longitudinal design to confirm whether HPWP and employees' innovative behavior are leading 4- and 5-star hotels to maintain or gain a competitive edge. Second, the research's data were collected in North Cyprus and precisely from 4- and 5-star hotels, and therefore a generalization to the entire hospitality industry would be far-fetched and imprudent. Perspectives from other destinations and hospitality facilities other than hotels would be valuable to the literature. For example, some of the HPWP dimensions used in our study may not be so critical in different service contexts. Therefore, future studies should adopt HPWP specifically to the service context from which the sample would be derived [101]. This research used employee creativity as a moderator variable, future research should identify and explore the role of other individual or higher-order moderators, which may give strength and add extra value to the proposed relationships [102].

Author Contributions: Conceptualization, S.N.E., and S.W.B.; methodology, S.N.E.; investigation, S.N.E.; formal analysis, S.W.B.; writing - original draft preparation, S.W.B., S.N.E. and A.O.; writing-review and editing, S.W.B., and S.N.E.; visualization, S.N.E., and S.W.B.; supervision, A.O. All authors have read and agreed to the published version of the manuscript.

Funding: This research received no external funding.

Conflicts of Interest: The authors declare no conflict of interest.

\section{Appendix A}

Table A1. Research instruments.

\begin{tabular}{ccc}
\hline Variable & Item & Reference \\
\hline Empowerment & E1. I am empowered to solve customer problems. & \\
& E2. I am encouraged to handle customer problems by myself. & \\
& E3. I do not have to get management's approval before I handle customer problems. & E4. I am allowed to do almost anything to solve customer problems. \\
E5. I have control over how I solve customer problems. & Hayes [75] \\
T1. I receive continued training to provide good service. & \\
Training & T3. I receive training on how to serve customers better. & \\
& T2. I received extensith customers. & Boshoff and \\
& T4. I receive training on how to deal with complaining customers. & Allen [74] \\
T5. I receive training on dealing with customer problems. & T6. I was trained to deal with customer complaints. & \\
\hline & RWD1. If I improve the level of service I offer customers, I will be rewarded. & Boshoff and \\
RWD2. The rewards I receive are based on customer evaluations of service. & Allen [74] \\
RWD3. I am rewarded for serving customers well. & \\
\hline
\end{tabular}


Table A1. Cont.

\begin{tabular}{|c|c|c|}
\hline Variable & Item & Reference \\
\hline $\begin{array}{l}\text { Selective } \\
\text { staffing }\end{array}$ & $\begin{array}{l}\text { SS1. In this workplace, great effort is taken to select the right person. } \\
\text { SS2. In this workplace, long-term employee potential is emphasized. } \\
\text { SS3. In this workplace, considerable importance is place on the staffing process. } \\
\text { SS4. In this workplace, very extensive efforts are made in selection. }\end{array}$ & $\begin{array}{c}\text { Sun, Aryee, } \\
\text { and Law [76] }\end{array}$ \\
\hline Teamwork & $\begin{array}{l}\text { TW1. Employees in my workgroup work together effectively. } \\
\text { TW2. There is a strong team spirit in my workgroup. } \\
\text { TW3. There is a lot of cooperation in my workgroup. } \\
\text { TW4. Employees in my workgroup are willing to put themselves out for the sake of the group. } \\
\text { TW5. Employees in my workgroup encourage each other to work as a team }\end{array}$ & $\begin{array}{l}\text { Coyle-Shapiro and } \\
\text { Morrow [77] }\end{array}$ \\
\hline $\begin{array}{l}\text { Employee } \\
\text { creativity }\end{array}$ & $\begin{array}{l}\text { EC1. He/ She suggests new ways to achieve goals and objectives } \\
\text { EC2. He/ She comes up with new and practical ideas to improve performance } \\
\text { EC3. He/ She searches out new technologies, processes, techniques, and/or product ideas } \\
\text { EC4. He/ She suggests new ways to increase quality } \\
\text { EC5. He/ She has a good source of creative ideas } \\
\text { EC6. He/ She is not afraid to take risks } \\
\text { EC7. He/ She promotes and champions ideas to others } \\
\text { EC8. He/ She exhibits creativity on the job when given the opportunity } \\
\text { EC 9. He/ She develops adequate plans and schedules for the implementation of new ideas } \\
\text { EC11. He/ She comes up with creative solutions to problems } \\
\text { EC12. He/ She often has a fresh approach to problems } \\
\text { EC13. He/ She suggests new ways of performing work tasks }\end{array}$ & $\begin{array}{c}\text { George and } \\
\text { Zhou [78] }\end{array}$ \\
\hline $\begin{array}{l}\text { Innovative } \\
\text { behaviors }\end{array}$ & $\begin{array}{l}\text { IB1. At work, employee } X \text { often seeks new modes and methods of service. } \\
\text { IB2. At work, employee } X \text { sometimes proposes his/her creative idea and tries to convince others. } \\
\text { IB3. At work, employee } X \text { sometimes comes up with innovative and creative notions. } \\
\text { IB4. At work, employee X provides a suitable plan for developing new ideas. } \\
\text { IB5. At work, employee X try to secure the funding and resources needed to implement innovations. } \\
\text { IB6. Overall, employee X considers him-/herself self as a creator. }\end{array}$ & $\begin{array}{l}\text { Hu, Horng, } \\
\text { and Sun [79] }\end{array}$ \\
\hline $\begin{array}{l}\text { Competitive } \\
\text { advantage }\end{array}$ & $\begin{array}{l}\text { CA1. Our hotel is of a superior quality than that of the competitors. } \\
\text { CA2. Our services or products are differentiated from other hotels. } \\
\text { CA3. Our hotel offer unique benefits than competitors. } \\
\text { CA4. Our services or product are more advanced than those in the same market. }\end{array}$ & Wu and Chen [80] \\
\hline
\end{tabular}

\section{References}

1. Lu, V.N.; Wirtz, J.; Kunz, W.H.; Paluch, S.; Gruber, T.; Martins, A.; Patterson, P.G. Service robots, customers, and service employees: What can we learn from the academic literature and where are the gaps? J. Serv. Theory Pract. 2020, 1-47. [CrossRef]

2. Bani-Melhem, S.; Zeffane, R.; Albaity, M. Determinants of employees' innovative behavior. Int. J. Contemp. Hosp. Manag. 2018, 30, 1601-1620. [CrossRef]

3. Li, M.; Hsu, C.H.C. A review of employee innovative behavior in services. Int. J. Contemp. Hosp. Manag. 2016, 28, 2820-2841. [CrossRef]

4. Rousseau, M.B.; Mathias, B.D.; Madden, L.T.; Crook, T.R. Innovation, Firm Performance, and Appropriation: A Meta-Analysis. Int. J. Innov. Manag. 2016, 20, 1650033. [CrossRef]

5. Services, Value Added (\% of GDP)—Data-World Bank. Available online: https://data.worldbank.org/ indicator/NV.SRV.TOTL.ZS?view=chart (accessed on 1 April 2020).

6. Storey, C.; Cankurtaran, P.; Papastathopoulou, P.; Hultink, E.J. Success Factors for Service Innovation: A Meta-Analysis. J. Prod. Innov. Manag. 2016, 33, 527-548. [CrossRef]

7. Bäckström, I.; Bengtsson, L. A mapping study of employee innovation: Proposing a research agenda. Eur. J. Innov. Manag. 2019, 22, 468-492. [CrossRef]

8. Åmo, B.W.; Kolvereid, L. Organizational strategy, individual Personality and innovation Behavior. J. Enterp. Cult. 2005, 13, 7-19. [CrossRef]

9. Dhar, R.L. The effects of high performance human resource practices on service innovative behaviour. Int. J. Hosp. Manag. 2015, 51, 67-75. [CrossRef]

10. Ottenbacher, M.C. Innovation Management in the Hospitality Industry: Different Strategies for Achieving Success. J. Hosp. Tour. Res. 2007, 31, 431-454. [CrossRef]

11. Yuan, F.; Woodman, R.W. Innovative behavior in the workplace: The role of performance and image outcome expectations. Acad. Manag. J. 2010, 53, 323-342. [CrossRef]

12. Lee, C.; Hallak, R.; Sardeshmukh, S.R. Creativity and innovation in the restaurant sector: Supply-side processes and barriers to implementation. Tour. Manag. Perspect. 2019, 31, 54-62. [CrossRef] 
13. Biemans, W.G.; Griffin, A.; Moenaert, R.K. New Service Development: How the Field Developed, Its Current Status and Recommendations for Moving the Field Forward. J. Prod. Innov. Manag. 2016, 33, 382-397. [CrossRef]

14. Kuester, S.; Schuhmacher, M.C.; Gast, B.; Worgul, A. Sectoral heterogeneity in new service development: An exploratory study of service types and success factors. J. Prod. Innov. Manag. 2013, 30, 533-544. [CrossRef]

15. de Winne, S.; Sels, L. Interrelationships between human capital, HRM and innovation in Belgian start-ups aiming at an innovation strategy. Int. J. Hum. Resour. Manag. 2010, 21, 1863-1883. [CrossRef]

16. Danaei, A.; Farzaneh, I. Key drivers of innovative behavior in hotel industry: Evidence from a developing country. Iran. J. Menag. Stud. 2016, 9, 599-625.

17. Edghiem, F.; Mouzughi, Y. Knowledge-advanced innovative behaviour: A hospitality service perspective. Int. J. Contemp. Hosp. Manag. 2018, 30, 197-216. [CrossRef]

18. Karatepe, O.M.; Ozturk, A.; Kim, T.T. Servant leadership, organisational trust, and bank employee outcomes. Serv. Ind. J. 2019, 39, 86-108. [CrossRef]

19. Afsar, B.; Badir, Y. Workplace spirituality, perceived organizational support and innovative work behavior: The mediating effects of person-organization fit. J. Workp. Learn. 2017, 29, 95-109. [CrossRef]

20. Kim, T.T.; Lee, G. Hospitality employee knowledge-sharing behaviors in the relationship between goal orientations and service innovative behavior. Int. J. Hosp. Manag. 2013, 34, 324-337. [CrossRef]

21. Li, M.; Hsu, C.H.C. Linking customer-employee exchange and employee innovative behavior. Int. J. Hosp. Manag. 2016, 56, 87-97. [CrossRef]

22. Dhar, R.L. Ethical leadership and its impact on service innovative behavior: The role of LMX and job autonomy. Tour. Manag. 2016, 57, 139-148. [CrossRef]

23. Kim, M.S.; Koo, D.W. Linking LMX, engagement, innovative behavior, and job performance in hotel employees. Int. J. Contem. Hosp. Manag. 2017, 29, 3044-3062. [CrossRef]

24. Barney, J. Firm Resources and Sustained Competitive Advantage. J. Manag. 1991, 17, 99-120. [CrossRef]

25. Bakker, A.B.; Demerouti, E. The Job Demands-Resources model: State of the art. J. Manag. Psychol. 2007, 22, 309-328. [CrossRef]

26. Sanders, K.; Lin, C.H.V. Human resource management and innovative behaviour: Considering interactive, informal learning activities. Hum. Resour. Manag. Innov. Perform. 2016, 32-47. [CrossRef]

27. Fu, N.; Flood, P.C.; Bosak, J.; Morris, T.; O’Regan, P. How do high performance work systems influence organizational innovation in professional service firms? Empl. Relat. 2015, 37, 209-231. [CrossRef]

28. Lewicka, D. Supporting innovation through HRM practices-Importance of motivation. Int. J. Innov. Learn. 2013, 14, 217-240. [CrossRef]

29. Prieto, I.M.; Pérez-Santana, M.P. Managing innovative work behavior: The role of human resource practices. Pers. Rev. 2014, 43, 184-208. [CrossRef]

30. Carda, N.E. High Performance Work Systems and Employee Innovative Behaviour. Ph.D. Thesis, University of Valencia, Valencia, Spain, 2015; pp. 1-246.

31. Escribá-Carda, N.; Balbastre-Benavent, F.; Teresa Canet-Giner, M. Employees' perceptions of high-performance work systems and innovative behaviour: The role of exploratory learning. Eur. Manag. J. 2017, 35, 273-281. [CrossRef]

32. Bos-Nehles, A.C.; Veenendaal, A.A.R. Perceptions of HR practices and innovative work behavior: The moderating effect of an innovative climate. Int. J. Hum. Resour. Manag. 2019, 30, 2661-2683. [CrossRef]

33. Sanz-Valle, R.; Jiménez-Jiménez, D. HRM and product innovation: Does innovative work behaviour mediate that relationship? Manag. Decis. 2018, 1417-1429. [CrossRef]

34. Odoardi, G. The relationship of perceived Human Resources Management Practices and Innovative Work Behavior. Ph.D. Thesis, Université de Bordeaux, Bordeaux, France, 2018.

35. Xerri, M.J.; Reid, S.R.M. Human resources and innovative behaviour: Improving nursing performance. Int. J. Innov. Manag. 2018, 22, 1850019. [CrossRef]

36. Ansari, N.Y.; Siddiqui, S.H.; Farrukh, M. The Effect of High-Performance Work Practices on Employee Innovative Behavior: The Mediating Role of Job Embeddedness. Int. J. Contemp. Econ. Adm. Sci. 2018, 8, 64-88.

37. Jaiswal, D.; Tyagi, A. Effect of high-performance work practices on service innovative behavior. Tour. Rev. 2019, 75, 382-401. [CrossRef]

38. van Esch, E.; Wei, L.Q.; Chiang, F.F.T. High-performance human resource practices and firm performance: The mediating role of employees' competencies and the moderating role of climate for creativity. Int. J. Hum. Resour. Manag. 2018, 9, 1683-1708. [CrossRef] 
39. Anderson, N.; Potočnik, K.; Zhou, J. Innovation and Creativity in Organizations: A State-of-the-Science Review, Prospective Commentary, and Guiding Framework. J. Manag. 2014, 40, 1297-1333. [CrossRef]

40. Hon, A.H.Y.; Lui, S.S. Employee creativity and innovation in organizations: Review, integration, and future directions for hospitality research. Int. J. Contemp. Hosp. Manag. 2016, 28, 862-885. [CrossRef]

41. Seeck, H.; Diehl, M.R. A literature review on HRM and innovation-taking stock and future directions. Int. J. Hum. Resour. Manag. 2017, 28, 913-944. [CrossRef]

42. Amabile, T.M. Creativity and Innovation in Organizations Amabile; Harvard Business School: Boston, MA, USA, 1996.

43. Karatepe, O.M.; Avci, T.; Tekinkus, M. Measuring marketing culture: A study of frontline employees in turkish hotels. J. Travel. Tour. Mark. 2005, 18, 33-47. [CrossRef]

44. Uzkurt, C.; Kumar, R.; Kimzan, H.S.; Eminoğlu, G. Role of innovation in the relationship between organizational culture and firm performance: A study of the banking sector in Turkey. Eur. J. Innov. Manag. 2013, 16, 92-117. [CrossRef]

45. Taştan, S.B.; Davoudi, S.M.M. An Examination of the Relationship between Leader-member Exchange and Innovative Work Behavior with the Moderating Role of Trust in Leader: A Study in the Turkish Context. Proc. Soc. Behav. Sci. 2015, 181, 23-32. [CrossRef]

46. Ghafoor, N.; Qureshi, T.M. Human capital causative model: Mediating effect of high-performance work system. Afr. J. Bus. Manag. 2013, 7, 1276.

47. Snell, S.S.M.; Wright, P. Human Resources Strategy: The Era of Our Ways. In The Blackwell Handbook of Strategic Management; Wiley: Hoboken, NJ, USA, 2001; pp. 627-649.

48. Barney, J.B.; Wright, P.M. On becoming a strategic partner: The role of human resources in gaining competitive advantage. Hum. Resour. Manag. 1998, 37, 31-46. [CrossRef]

49. Connolly, P.; McGing, G. High performance work practices and competitive advantage in the Irish hospitality sector. Int. J. Contemp. Hosp. Manag. 2007, 19, 201-210. [CrossRef]

50. Hamadamin, H.H.; Atan, T. The impact of strategic human resource management practices on competitive advantage sustainability: The mediation of human capital development and employee commitment. Sustainability 2019, 11, 5782. [CrossRef]

51. Messersmith, J.G.; Guthrie, J.P. High performance work systems in emergent organizations: Implications for firm performance. Hum. Resour. Manag. 2010, 49, 241-264. [CrossRef]

52. Kim, Y.; Ployhart, R.E. The effects of staffing and training on firm productivity and profit growth before, during, and after the great recession. J. Appl. Psychol. 2014, 99, 361. [CrossRef]

53. Skaggs, B.C.; Youndt, M. Strategic positioning, human capital, and performance in service organizations: A customer interaction approach. Strateg. Manag. J. 2004, 25, 85-99. [CrossRef]

54. Youndt, M.; Snell, S. Human Resource Configurations, Intellectual Capital, and Organizational Performance. J. Manag. Issues 2004, 16, 337-360.

55. Chowhan, J. Unpacking the black box: Understanding the relationship between strategy, HRM practices, innovation and organizational performance. Hum. Resour. Manag. J. 2016, 26, 112-133. [CrossRef]

56. Curran, B.; Walsworth, S. Can you pay employees to innovate? Evidence from the Canadian private sector. Hum. Resour. Manag. J. 2014, 24, 290-306. [CrossRef]

57. $\mathrm{Fu}, \mathrm{N}$. The role of relational resources in the knowledge management capability and innovation of professional service firms. Hum. Relat. 2015, 68, 731-764. [CrossRef]

58. Mazzei, M.J.; Flynn, C.B.; Haynie, J.J. Moving beyond initial success: Promoting innovation in small businesses through high-performance work practices. Bus. Horiz. 2016, 59, 51-60. [CrossRef]

59. Chatzoglou, P.; Chatzoudes, D. The role of innovation in building competitive advantages: An empirical investigation. Eur. J. Innov. Manag. 2018, 21, 44-69. [CrossRef]

60. Liu, C.H. Creating competitive advantage: Linking perspectives of organization learning, innovation behavior and intellectual capital. Int. J. Hosp. Manag. 2017, 66, 13-23. [CrossRef]

61. Jiang, K.; Lepak, D.P.; Hu, J.; Baer, J.C. How does human resource management influence organizational outcomes? A meta-analytic investigation of mediating mechanisms. Acad. Manag. J. 2012, 55, 1264-1294. [CrossRef]

62. Chang, S.; Gong, Y.; Way, S.A.; Jia, L. Flexibility-Oriented HRM Systems, Absorptive Capacity, and Market Responsiveness and Firm Innovativeness. J. Manag. 2013, 39, 1924-1951. [CrossRef] 
63. Sulaiman, I.F.; Hashim, C.N.; Ibrahim, M.B.; Hassan, S.S.S. Impact of Creativity to Organizational Competitiveness. Int. J. Hum. Soc. Sci. 2015, 5, 106-113.

64. Ali Thawabieh, D.F.; Saleem, M. Organizational Creativity and Competitive Advantage: A GCC Perspective. Int. J. Econ. Manag. Sci. 2016, 5, 2. [CrossRef]

65. Caniëls, M.C.J.; Rietzschel, E.F. Organizing creativity: Creativity and innovation under constraints. Creat. Innov. Manag. 2015, 24, 184-196. [CrossRef]

66. Amabile, T.M.; Pratt, M.G. The dynamic componential model of creativity and innovation in organizations: Making progress, making meaning. Res. Organ. Behav. 2016, 36, 157-183. [CrossRef]

67. Liu, D.; Jiang, K.; Shalley, C.E.; Keem, S.; Zhou, J. Motivational mechanisms of employee creativity: A meta-analytic examination and theoretical extension of the creativity literature. Organ. Behav. Hum. Decis. Proces. 2016, 137, 236-263. [CrossRef]

68. Harari, M.B.; Reaves, A.C.; Viswesvaran, C. Creative and innovative performance: A meta-analysis of relationships with task, citizenship, and counterproductive job performance dimensions. Eur. J. Work. Organ. Psychol. 2016, 25, 495-511. [CrossRef]

69. Sarooghi, H.; Libaers, D.; Burkemper, A. Examining the relationship between creativity and innovation: A meta-analysis of organizational, cultural, and environmental factors. J. Bus. Ventur. 2015, 30, 714-731. [CrossRef]

70. Rank, J.; Pace, V.L.; Frese, M. Three avenues for future research on creativity, innovation, and initiative. Appl. Psychol. 2004, 53, 518-528. [CrossRef]

71. Schaufeli, W.B. Applying the Job Demands-Resources model: A 'how to' guide to measuring and tackling work engagement and burnout. Organ. Dyn. 2017, 46, 120-132. [CrossRef]

72. Podsakoff, P.M.; MacKenzie, S.B.; Podsakoff, N.P. Sources of Method Bias in Social Science Research and Recommendations on How to Control It. Annu. Rev. Psychol. 2012, 63, 539-569. [CrossRef]

73. Mcgorry, S.Y. Measurement in a cross-cultural environment: Survey translation issues. Qualitative Mark. Res. Int. J. 2000, 3, 74-81. [CrossRef]

74. Boshoff, C.; Allen, J. The influence of selected antecedents on frontline staff's perceptions of service recovery performance. Int. J. Serv. Ind. Manag. 2000, 11, 63-90. [CrossRef]

75. Hayes, B.E. How to measure empowerment. Qual. Prog. 1994, 27, 41-46.

76. Sun, L.Y.; Aryee, S.; Law, K.S. High-performance human resource practices, citizenship behavior, and organizational performance: A relational perspective. Acad. Manag. J. 2007, 50, 558-577. [CrossRef]

77. Coyle-Shapiro, J.A.M.; Morrow, P.C. The role of individual differences in employee adoption of TQM orientation. J. Vocat. Behav. 2003, 62, 320-340. [CrossRef]

78. George, J.M.; Zhou, J. When openness to experience and conscientiousness are related to creative behavior: An interactional approach. J. Appl. Psychol. 2001, 86, 513-524. [CrossRef] [PubMed]

79. Hu, M.L.; Horng, J.S.; Sun, Y.H. Hospitality teams: Knowledge sharing and service innovation performance. Tour. Manag. 2009, 30, 41-50.

80. Wu, J.; Chen, X. Leaders' social ties, knowledge acquisition capability and firm competitive advantage. Asia Pac. J. Manag. 2012, 29, 331-350. [CrossRef]

81. Anderson, J.C.; Gerbing, D.W. Structural Equation Modeling in Practice: A Review and Recommended Two-Step Approach. Psychol. Bull. 1988, 103, 411-423. [CrossRef]

82. Hair, J.F.; Black, W.C.; Babin, B.J.; Anderson, R.E.; Tatham, R.L. Multivariate Data Analysis; Prentice Hall: Upper Saddle River, NJ, USA, 2010; p. 101.

83. Fornell, C.; Larcker, D.F. Evaluating Structural Equation Models with Unobservable Variables and Measurement Error. J. Mark. Res. 1981, 8, 39-50. [CrossRef]

84. Nunnally, J.C. Psychometric Theory; McGraw-Hill Education: New York, NY, USA, 1978.

85. Agostini, L.; Nosella, A.; Filippini, R. Towards an Integrated View of the Ambidextrous Organization: A Second-Order Factor Model. Creativ. Innov. Manag. 2016, 25, 129-141. [CrossRef]

86. Marsh, H.W.; Hocevar, D. Application of Confirmatory Factor Analysis to the Study of Self-Concept. Firstand Higher Order Factor Models and Their Invariance Across Groups. Psychol. Bull. 1985, 97, 562. [CrossRef]

87. Davis-Becker, K.; Peterson, C.M.; Fischer, S. The relationship of trait negative urgency and negative affect to disordered eating in men and women. Personal. Individ. Differ. 2014, 1, 9-14. [CrossRef]

88. Iacobucci, D. Structural equations modeling: Fit Indices, sample size, and advanced topics. J. Consum. Psychol. 2010, 20, 90-98. [CrossRef]

89. Zhang, H.; Xu, H. A structural model of liminal experience in tourism. Tour. Manag. 2019, 71, 84-98. [CrossRef] 
90. Bufquin, D.; DiPietro, R.; Orlowski, M.; Partlow, C. The influence of restaurant co-workers' perceived warmth and competence on employees' turnover intentions: The mediating role of job attitudes. Int. J. Hosp. Manag. 2017, 60, 13-22. [CrossRef]

91. Hayes, A.F. Introduction to Mediation, Moderation, and Conditional Process Analysis: A Regression-Based Approach; The Guilford Press: New York, NY, USA, 2017.

92. Fu, N.; Flood, P.C.; Bosak, J.; Rousseau, D.M.; Morris, T.; O’Regan, P. High-Performance Work Systems in Professional Service Firms: Examining the Practices-Resources-Uses-Performance Linkage. Hum. Resour. Manag. 2017, 56, 329-352. [CrossRef]

93. Saridakis, G.; Lai, Y.; Cooper, C.L. Exploring the relationship between HRM and firm performance: A meta-analysis of longitudinal studies. Hum. Resour. Manag. Rev. 2017, 27, 87-96. [CrossRef]

94. Anning-Dorson, T. Innovation and competitive advantage creation: The role of organisational leadership in service firms from emerging markets. Int. Mark. Rev. 2018, 35, 580-600. [CrossRef]

95. Song, W.; Yu, H. Green Innovation Strategy and Green Innovation: The Roles of Green Creativity and Green Organizational Identity. Corp. Soc. Responsib. Environ. Manag. 2018, 25, 135-150. [CrossRef]

96. Teece, D.J. Explicating dynamic capabilities: The nature and microfoundations of (sustainable) enterprise performance. Strateg. Manag. J. 2007, 28, 1319-1350. [CrossRef]

97. HofstedeInsights. Country Comparison. 2019. Available online: https://www.hofstede-insights.com/countrycomparison/turkey/ (accessed on 5 May 2019).

98. Özduran, A.; Tanova, C. Coaching and employee organizational citizenship behaviours: The role of procedural justice climate. Int. J. Hosp. Manag. 2017, 60, 58-66. [CrossRef]

99. Özduran, A.; Tanova, C. Manager mindsets and employee organizational citizenship behaviours. Int. J. Contemp. Hosp. Manag. 2017, 29, 589-606. [CrossRef]

100. Martin, L.; Groves, J. Interviews as a selection tool for entry-level hospitality employees. J. Hum. Resour. Hosp. Tour. 2002, 1, 41-47. [CrossRef]

101. Murphy, K.; Torres, E.; Ingram, W.; Hutchinson, J. A review of high performance work practices (HPWPs) literature and recommendations for future research in the hospitality industry. Int. J. Contemp. Hosp. Manag. 2018, 30, 365-388. [CrossRef]

102. Albrecht, S.L.; Bakker, A.B.; Gruman, J.A.; Macey, W.H.; Saks, A.M. Employee engagement, human resource management practices and competitive advantage: An integrated approach. J. Effectiveness 2015, 2, 7-35. [CrossRef]

(C) 2020 by the authors. Licensee MDPI, Basel, Switzerland. This article is an open access article distributed under the terms and conditions of the Creative Commons Attribution (CC BY) license (http://creativecommons.org/licenses/by/4.0/). 